\title{
A series of 6 cases of systemic lupus erythematosus in pregnancy
}

\author{
Shruti Ashok Panchbudhe*, Meena Naresh Satia, J. Madhavi
}

\begin{abstract}
Department of Obstetrics and Gynaecology, Seth Gordhandas Sunderdas Medical College and King Edward VII Memorial Hospital, Mumbai, Maharashtra, India
\end{abstract}

Received: 25 September 2016

Revised: 24 October 2016

Accepted: 22 October 2016

\section{*Correspondence:}

Dr. Shruti Ashok Panchbudhe,

E-mail: shrutipanchbudhe@gmail.com

Copyright: (c) the author(s), publisher and licensee Medip Academy. This is an open-access article distributed under the terms of the Creative Commons Attribution Non-Commercial License, which permits unrestricted non-commercial use, distribution, and reproduction in any medium, provided the original work is properly cited.

\begin{abstract}
Background: Systemic lupus erythematosus (SLE) is a type of chronic inflammatory connective tissue disease commonly diagnosed between the ages of 20-30 It is more common in women than in men, especially during the fertile period of a women's life. In olden days pregnancy in patients with SLE were discouraged due to concern regarding the poor feto-maternal outcomes. However, over the last 10-15 years, medical practice has changed, and in many cases pregnancy is possible with close supervision, and advice tailored according to individual cases. This case series will explain what care need to be taken into consideration prior to conception, ANC period and post pregnancy 100.

Methods: This was a retrospective study conducted at Seth G. S. M. C. and KEM Hospital Parel after IEC approval where 6 cases of Systemic Lupus Erythematosus in pregnancy over a period of 1 year in a unit were collected and are presented here with regards to maternal and fetal outcomes.

Results: In our case series two patients required Caesarean section for fetal indication and both the babies had congenital heart block and were asked regular follow up in cardiology outpatient department, two patients required medical termination of pregnancy in view of teratogenic drug exposure(cyclophosphamide), one patient had intrauterine growth restriction and had a preterm vaginal delivery with good fetal outcome and no heart block in the baby and the last patient was diagnosed as a case of SLE when baby was found to have heart block in the antenatal period and was later evaluated and diagnosed as a case of SLE.

Conclusions: Lupus activity is increased in pregnancy and patients with SLE are at higher risk for spontaneous abortions, fetal death, PIH, preterm delivery and intrauterine growth retardation. Management of these cases requires a multidisciplinary approach involving the obstetrician, rheumatologist, nephrologist and neonatologist.
\end{abstract}

Keywords: Neonatal lupus syndrome, Systemic lupus erythematosus

\section{INTRODUCTION}

Systemic Lupus Erythematosus is an autoimmune disorder which affects the women during their childbearing years. Women with SLE may have many complications during pregnancy one third may require caesarean section, $33 \%$ will have preterm birth, and over $20 \%$ of patients may develop PIH. ${ }^{1,2}$ Lupus exacerbation during pregnancy occurs in about $20-30 \%$ of pregnant lupus patients. These SLE flares are uncommon during pregnancy and are easily treated. The maternal and fetal prognosis are best when SLE is quiescent for at least 6 months prior to pregnancy and when the mother's underlying renal function parameter are normal or near normal. The maternal and fetal wellbeing should be monitored frequently during pregnancy. Increased SLE flares during pregnancy is because of increased levels of estrogen, prolactin, and T-helper cell 2 cytokines and flares during the postpartum period is probably due to decreased levels of anti-inflammatory steroid, increased 
prolactin levels, changes in the neuroendocrine axis, and estrogen and progesterone changes. ${ }^{3}$

\section{METHODS}

This was a retrospective study conducted at Seth G. S. M. C. and KEM Hospital Parel, where 6 cases of Systemic Lupus Erythematosus in pregnancy over a period of 1 year were collected and are presented here with regards to maternal and fetal outcomes. The history of these patients was collected by reviewing the indoor papers and included demographic details, details of the current pregnancy, maternal outcome, fetal outcome, laboratory investigations and treatment offered pertaining to SLE.

\section{Case series}

A series of 6 cases of SLE in pregnancy are presented here:

\section{Case 1}

28 years old married since 4 years, G2P1IUFD1 presented to the antenatal outpatient department at 32 weeks of gestation for registration in view of diagnosed case patient SLE. She had a previous intrauterine foetal demise at 32 weeks of gestation in view of severe intrauterine growth restriction with pregnancy induced hypertension of baby weighing 900 grams. Post-delivery her lupus anticoagulant and Anticardiolipin antibodies were negative and Antinuclear antibodies and Double stranded DNA was positive(1:40 titres).She was diagnosed with SLE and was started by rheumatologist on Tab Aspirin $75 \mathrm{mg}$ OD, Tablet Azathioprine $300 \mathrm{mg}$ OD, Tablet Prednisolone40 mg OD and Tab Hydroxychloroquine 200mg OD. She conceived one year after her first pregnancy and was taking the following medications as advised by rheumatologist and had regular antenatal visits with a private obstetrician. After registration at our centre her rheumatology reference was done and she was advised to continue the same medications and a Foetal 2 echo was done which was suggestive of second degree heart block in the baby. She underwent a Elective LSCS in view of precious pregnancy with baby having hear block at 38 weeks of gestation and delivered a male baby of $3.2 \mathrm{~kg}$ with Apgar score of 9/10. Baby was shifted to the NICU and post delivery 2D Echo was done in which the findings of second degree heart block were confirmed but did not required any intervention and was asked to follow up regularly in cardiology OPD at 6 monthly interval.

\section{Case 2}

34 years married since 12 years G4P3L3 10.3 weeks of gestation diagnosed case of SLE with lupus nephritis was admitted for medical termination of pregnancy. Patient was diagnosed as a case of SLE 2 years back, started on steroids and ANA blot was done which was negative and renal biopsy done was suggestive of class IV Diffuse lupus nephritis. She was started on T. Prednisolone 50 $\mathrm{mg}$ OD, T. Hydroxychloroquine $300 \mathrm{mg}$ OD, T. Telmesartan $20 \mathrm{mg}$ OD and T. Aspirin $75 \mathrm{mg}$ OD. She was also a diagnosed case of hypothyroidism and was on T. Thyronorm. She was also started on Injection Cyclophosphamide 1 gram intravenously and was given monthly 7 doses followed by quarterly cycles of Injection Cyclophosphamide. She had taken the last dose of injection Cyclophosphamide and had also undergone a DEXA scan for steroid induced bone changes when she was pregnant (approximately 6 weeks) and was unaware of her pregnancy. She came to our OPD for missed periods where she was found to be pregnant and was considered for MTP on the grounds of substantial risk that the child was born would lead to such physical and mental abnormalities so as to be seriously handicapped. Her endocrinologist fitness was taken for hypothyroidism and cardiologist reference in view of Cyclophosphamide induced cardiomyopathy for which 2 D Echo was done which was normal. She underwent a medical termination of pregnancy by suction evacuation. Her postoperative recovery was uneventful and she was discharged on the same medications.

\section{Case 3}

28 years female primigravida with 34 weeks of gestation by dates diagnosed as a case of SLE 1 year back was admitted in medicine ward for loose motions, vomiting, fever with chills and erythematous rashes all over the body started on face, inframammary region and groin. She had regular follow up with private practioner and was taking T. Omnacortil $10 \mathrm{mg}$ OD, T. Azoran $50 \mathrm{mg}$ BD and T. Hydroxychlorine 200mg HS. After admission her liver function tests were done in which SGOT and SGPT were 375 and 404 respectively and viral markers were negative. A diagnosis of SLE with drug induced hepatitis was made and Tablet Azathioprine was stopped and rest of the drugs were continued. Her SS-A and SS-B were positive and ANA titres were 1:320 homogenous IF $3+$. Her foetal 2D Echo was done which was normal and Colour Doppler Obstetrics was done which was suggestive of single live intrauterine gestation of 33 weeks with uteroplacental insufficiency with oligohydramnios with AFI 5 to $6 \mathrm{~cm}$ and expected baby weight of $2 \mathrm{~kg}$. Her liver function test were monitored every third day and they were in the decreasing trends. She was advised biweekly Non stress test and strict daily foetal kick count. She had leaking per vaginum at 35.4 weeks and went into spontaneous labour. She progressed well and was given Injectable hydrocortisone $100 \mathrm{mg}$ intravenously at the time of labour. She delivered normally a female $2 \mathrm{~kg}$ with Apgar of 9/10. Her liver function tests at the time of discharge were SGOT and SGPT 52 and 65. Post-delivery her rheumatology reference was taken and she was discharged on the same medications. 


\section{Case 4}

27 year old married since 9 years primigravida with 35.1 weeks by dates with primary infertility, conceived with intrauterine insemination came to the emergency room with a from a remote village in view of foetal bradyarrythmia. She was a diagnosed as a case of SLE during this pregnancy at 18 weeks of gestation and was already started on $\mathrm{T}$. Aspirin $75 \mathrm{mg}$ OD, injection Heparin 5000 international units 6 hourly, T. Telmesartan $20 \mathrm{mg}$ OD, T. Atorvastatin Hs, t. Hydroxychloroquine $300 \mathrm{mg}$ OD, T. Prednisolone $5 \mathrm{mg}$ OD. She was a known case of polycystic ovarian disease prior to conception and was on T. Glycomet $850 \mathrm{mg}$. Her sugars throughout the antenatal period were controlled on T. Glycomet $850 \mathrm{mg}$ OD and diabetic diet. Her antenatal profile was normal. In her investigations SSA-RO was IgG positive, antinuclear antibodies were positive, Antiphospholipid antibodies $\operatorname{IgG}$ and $\operatorname{IgM}$ was positive. Her complement levels C3 was 153 and C4 was 35.4. After diagnosis of SLE based on the above reports she was started on the above medications. Her fetal malformation scan was normal but fetal 2 D Echo was suggestive of foetal bradycardia with no atrioventricular conduction block and no structural anomaly. After admission her Colour Doppler was done which was normal and biweekly NST was done which was reactive. Her rheumatology reference was done and she was asked to continue the same medications. She underwent an Elective lower segment caesarean section at 38 weeks in view of precious pregnancy and delivered a female $2.196 \mathrm{~kg}$ with Apgar of 9/10. Baby was shifted to NICU and underwent A 2 D echo which showed congenital heart block without structural anomaly. Cardiology reference was taken for the baby and was advised no active cardiac intervention at present and to follow in the cardiology OPD regularly. Rheumatology reference was taken post-delivery and was advised to continue the same medications and to convert Injection Heparin to T. Warfarin till a target INR of 1 was achieved. This INR was achieved on Tab warfarin $5 \mathrm{mg}$ which was continued and the dose of T. Aspirin was stepped up to $150 \mathrm{mg}$ OD.

\section{Case 5}

19 years old, Primigravida with 8 weeks of gestation with SLE with lupus nephritis Class IV diagnosed one year back at the time of presentation with fever. On evaluation for fever she was found to have pancytopenia and proteinuria. Her further tests were done in which her ANA was positive $3+$ and ds DNA was also positive. Her kidney biopsy was done in which she was found to have Class IV lupus nephritis for which she was given 4 cycles of Cyclophosphamide monthly. Patient had missed period and last cycle of Cyclophophamide was taken during missed period. She was also a known case of epilepsy and she was on Phenytoin $100 \mathrm{mg}$ BD for which her neurology fitness was taken. Her 2 D Echo was also done as she was on cyclophosphamide which was within normal limits. She was advised Medical termination of pregnancy at 8 weeks in view of fetal exposure to cyclophosphamide but procedure was delayed due to Urinary tract infection. Patient was on Tab aspirin 150 mg OD, Tab Hydroxyquinone $300 \mathrm{mg}$ OD, Tab Prednisolone $10 \mathrm{mg}$ OD and Tab. Atorvastatin $10 \mathrm{mg}$ Hs. Patient came at 14 weeks after UTI was controlled for second trimester termination of pregnancy. Procedure was done with the use of Misoprosteol $400 \mathrm{mg}$ every 4 hourly. The induction abortion interval was 12 hours her post abortion course was uneventful and she was discharged on the same medications.

\section{Case 6}

A 23 year old Gravida 2 Para 1 registered antenatally at our clinic in the second trimester she had a previous full term normal delivery. At 28 weeks gestation the fetal heart sounds were found to be irregular ranging from $60 /$ minute to $120 /$ minute, as heard on a stethoscope. She was advised admission for evaluation of possible fetal cardiac anomaly but did not get admitted. Ultrasonography for fetal malformations at 29 weeks showed evidence of fetal bradycardia (53 beats per minute) probably due to conduction defect with a complete heart block, mild pericardial effusion and reverse flow in ductus venosus suggestive of early fetal hydropss. As she was not willing for admission, she was advised to do investigations such as ANA, ds DNA, antiRo (SSA), anti-La (SSB) antibodies and blood sugars and was advised to follow up with the reports. Patient later returned to the hospital in active labor at 37.1 weeks and delivered uneventfully, female $1.6 \mathrm{~kg}$ with Apgar score of $8 / 10$. The neonate had Mongoloid features (slanting eyes, low set ears and depressed nasal bridge) with clinodactyly and bradycardia. Baby was shifted to the neonatal intensive care unit for evaluation. ECG of the neonate was suggestive of complete heart block with atrial rate of 160/minute and ventricular rate of 60/minute. Echocardiography showed a $3 \mathrm{~mm}$ atrial septal defect of ostium secundum type with no other cardiac anomalies. Cardiology opinion was taken who advised monthly follow up of the baby. The neonate's blood counts, hepatic and renal function tests were within normal limits. Karyotyping was suggestive of Trisomy 21. The baby was discharged on full feeds and advised to follow up with the above reports. On maternal evaluation, the patient tested positive for ANA antibodies, anti-Ro and anti-La antibodies and was negative for anti-dsDNA antibodies. Rheumatology opinion was sought and was advised investigations and started on drugs for SLE after evaluation. 
Table 1: Summary of cases of SLE.

\begin{tabular}{|c|c|c|c|c|c|}
\hline $\begin{array}{l}\text { Sr. } \\
\text { No. }\end{array}$ & $\begin{array}{l}\text { Patient } \\
\text { presentation }\end{array}$ & $\begin{array}{l}\text { Diagnosis and } \\
\text { Investigations for } \\
\text { SLE }\end{array}$ & Treatment of SLE & $\begin{array}{l}\text { Maternal } \\
\text { Outcome }\end{array}$ & Fetal Outcome \\
\hline $\begin{array}{l}\text { Case } \\
1\end{array}$ & $\begin{array}{l}\text { G2P1IUFD1 } \\
\text { with } 32 \text { weeks } \\
\text { of gestation with } \\
\text { IUGR and PIH }\end{array}$ & $\begin{array}{l}\text { Diagnosed SLE one } \\
\text { year back after her first } \\
\text { delivery and ANA and } \\
\text { dsDNA were positive } \\
\text { (1:40). Fetal 2D echo } \\
\text { showed second degree } \\
\text { heart block }\end{array}$ & $\begin{array}{l}\text { Aspirin, } \\
\text { Azathioprine, } \\
\text { Prednisolone, } \\
\text { Hydroxychloroquine }\end{array}$ & $\begin{array}{l}\text { Elective LSCS in } \\
\text { view of precious } \\
\text { pregnancy with } \\
\text { baby having heart } \\
\text { block at } 38 \text { weeks } \\
\text { of gestation }\end{array}$ & $\begin{array}{l}\text { Male } 3.2 \mathrm{~kg} \text { with Apgar } 9 / 10 \text {, Fetal } \\
2 \mathrm{D} \text { Echo showed second degree } \\
\text { heart block, No intervention } \\
\text { required and follow up in } \\
\text { cardiology OPD at } 6 \text { monthly } \\
\text { intervals. }\end{array}$ \\
\hline $\begin{array}{l}\text { Case } \\
2\end{array}$ & $\begin{array}{l}\text { G4P3L3 with } \\
10.3 \text { weeks with } \\
\text { Class IV lupus } \\
\text { nephritis }\end{array}$ & $\begin{array}{l}\text { Diagnosed SLE } 2 \\
\text { years back, ANA blot } \\
\text { negative and renal } \\
\text { biopsy showed class } \\
\text { IV Diffuse lupus } \\
\text { nephritis }\end{array}$ & $\begin{array}{l}\text { Prednisolone, } \\
\text { Hydroxychloroquine, } \\
\text { Telmesartan, Aspirin } \\
\text { Cyclophosphamide }\end{array}$ & $\begin{array}{l}\text { Underwent first } \\
\text { trimester MTP in } \\
\text { view of the child } \\
\text { was born would } \\
\text { lead to such } \\
\text { physical and mental } \\
\text { abnormalities so as } \\
\text { to be seriously } \\
\text { handicapped } \\
\text { (Cyclophosphamide } \\
\text { and DEXA scan } \\
\text { exposure) }\end{array}$ & - \\
\hline $\begin{array}{l}\text { Case } \\
3\end{array}$ & $\begin{array}{l}\text { Primigravida } \\
\text { with } 34 \text { weeks } \\
\text { of gestation with } \\
\text { SLE with drug } \\
\text { induced } \\
\text { hepatitis with } \\
\text { IUGR with } \\
\text { oligohydraminos }\end{array}$ & $\begin{array}{l}\text { Diagnosed SLE } 1 \text { year } \\
\text { back, SS-A and SS-B } \\
\text { positive and ANA } \\
\text { titers 1:320 } \\
\text { homogenous IF } \\
\text { 3+.Fetal 2D Echo } \\
\text { normal. }\end{array}$ & $\begin{array}{l}\text { Omnacortil, Azoran } \\
\text { Hydroxychloroquine }\end{array}$ & $\begin{array}{l}\text { Pre Term Vaginal } \\
\text { delivery at } 35.4 \\
\text { weeks }\end{array}$ & Female $2 \mathrm{~kg}$ with Apgar 9/10 \\
\hline $\begin{array}{l}\text { Case } \\
4\end{array}$ & $\begin{array}{l}\text { Primigravida } \\
\text { with } 35.1 \text { weeks } \\
\text { with primary } \\
\text { infertility, } \\
\text { conceived with } \\
\text { intrauterine } \\
\text { insemination } \\
\text { with donor } \\
\text { sperm with fetal } \\
\text { bradyarrythmia. }\end{array}$ & $\begin{array}{l}\text { Diagnosed SLE in } \\
\text { present pregnancy, } \\
\text { SSA-RO IgG positive, } \\
\text { ANA positive, } \\
\text { Antiphospholipid } \\
\text { antibodies IgG and } \\
\text { IgM positive. Fetal } 2 \\
\text { D Echo showed } \\
\text { bradyarrythmias }\end{array}$ & $\begin{array}{l}\text { Aspirin, Heparin } \\
\text { Telmesartan } \\
\text { Atorvastatin . } \\
\text { Hydroxychloroquine } \\
\text { and Prednisolone }\end{array}$ & $\begin{array}{l}\text { Elective LSCS at } \\
38 \text { weeks for } \\
\text { precious pregnancy }\end{array}$ & $\begin{array}{l}\text { Female } 2.196 \mathrm{~kg} \text { with Apgar 9/10. } \\
\text { Fetal 2D Echo showed congenital } \\
\text { heart block, No intervention } \\
\text { required and follow up in } \\
\text { cardiology OPD at } 6 \text { monthly } \\
\text { interval. }\end{array}$ \\
\hline $\begin{array}{l}\text { Case } \\
5\end{array}$ & $\begin{array}{l}\text { Primigravida } \\
\text { with } 8 \text { weeks } \\
\text { with SLE and } \\
\text { Class IV lupus } \\
\text { nephritis }\end{array}$ & $\begin{array}{l}\text { Diagnosed SLE with } \\
\text { Class IV lupus } \\
\text { nephritis } 1 \text { year back } \\
\text { when evaluation for } \\
\text { fever, pancytopenia } \\
\text { and proteinuria done. } \\
\text { ANA (3+) and dsDNA } \\
\text { positive }\end{array}$ & $\begin{array}{l}\text { Aspirin, } \\
\text { Hydroxyquinone, } \\
\text { Prednisolone } \\
\text { Atorvastatin, } \\
\text { Cyclophosphamide }\end{array}$ & $\begin{array}{l}\text { Second Trimester } \\
\text { Medical } \\
\text { Termination done } \\
\text { in view of child } \\
\text { was born would } \\
\text { lead to such } \\
\text { physical and mental } \\
\text { abnormalities so as } \\
\text { to be seriously } \\
\text { handicapped } \\
\text { (Cyclophosphamide } \\
\text { exposure) }\end{array}$ & - \\
\hline $\begin{array}{l}\text { Case } \\
6\end{array}$ & $\begin{array}{l}\text { G2P1L1 with } \\
31.5 \text { weeks with } \\
\text { fetal bradycardia } \\
\text { with hydrops }\end{array}$ & $\begin{array}{l}\text { Diagnosed SLE post } \\
\text { delivery as patient was } \\
\text { lost to follow up.ANA } \\
\text { and anti-Ro and anti- } \\
\text { La positive and } \\
\text { negative for anti- } \\
\text { dsDNA antibodies. }\end{array}$ & & $\begin{array}{l}\text { Full term normal } \\
\text { vaginal delivery at } \\
\text { term }\end{array}$ & $\begin{array}{l}\text { Female } 1.672 \mathrm{~kg} \text {, Apgar score of } \\
8 / 10 \text {, Mongoloid features (slanting } \\
\text { eyes, low set ears and depressed } \\
\text { nasal bridge) with clinodactyly and } \\
\text { bradycardia. Shifted to NICU, ECG } \\
\text { suggestive of complete heart block } \\
\text { with atrial rate of } 160 / \text { minute and } \\
\text { ventricular rate of } 60 / \text { minute. } \\
\text { Echocardiography showed a } 3 \mathrm{~mm} \\
\text { atrial septal defect of ostium } \\
\text { secundum type and karyotype } \\
\text { suggestive of Down's syndrome }\end{array}$ \\
\hline
\end{tabular}




\section{RESULTS}

In our case series two patients required Caesarean section for fetal indication and both the babies had congenital heart block and were asked regular follow up in cardiology outpatient department, two patients required medical termination of pregnancy in view of teratogenic drug exposure (cyclophosphamide), one patient had intrauterine growth restriction and a preterm vaginal delivery with good fetal outcome and no heart block in the baby and the last patient was diagnosed as a case of SLE when baby was found to have heart block in the antenatal period and was later evaluated and diagnosed as a case of SLE. This baby was later diagnosed as a case of Downs syndrome.

\section{DISCUSSION}

SLE is a type of autoimmune and chronic inflammatory disorder affecting multiple organ systems which is characterised by exacerbations and remissions. SLE occurs in $90 \%$ of women and this predilection for the female gender is thought to be due to the influence of the hormone oestrogen. The female to male ratio peaks at 11:1 during the childbearing years. It is associated with deposition of immune complexes causing inflammation in vascular beds which leads to polyclonal B-cell activation that leads to antinuclear antibody production. This leads to complement deficiencies and impairment of $\mathrm{T}$-cell regulation which causes a failure to remove these immune complexes.

\section{Pre pregnancy counseling}

Active SLE in the early gestational period is known to be the strongest and best predictor of adverse pregnancy outcomes and hence, all pregnancies in these women should be planned during periods of disease remission. Women with SLE should be seen in the pre-pregnancy period to ascertain the suitability of conception depending on the level of the disease activity of the individual. They should be also counseled for potential obstetric problems including pregnancy loss, preterm birth, pre-eclampsia and growth restriction. They should be screened for anti-Ro (SS-A)/anti-La (SS-B) and antiphospholipid antibodies as they require close monitoring during pregnancy. The longer the woman is in remission, the better is the pregnancy outcome. Immunosuppressive drugs like methotrexate, mycophenolate and cyclophosphamide should be stopped at least three months prior to conception. Other immunosuppressive drugs such as azathioprine and cyclosporine may be continued if the benefits of the drug use during pregnancy outweigh the risks.

Table 2: Pre-pregnancy tests done to assess organ involvement includes.

\begin{tabular}{|ll|l|}
\hline Organ system & Manifestations & Investigations \\
\hline Cardiac & $\begin{array}{l}\text { Pulmonary Hemorrhage, Valvular } \\
\text { Heart Disease, Cardiomyopathy }\end{array}$ & Echocardiography \\
\hline Respiratory & Pulmonary Fibrosis & Chest X-Ray, CT Lungs, Pulmonary function Tests \\
\hline Renal & Proteinuria, Hematuria & Urine dipstick, Protein: Creatinine ratio, Renal Function Test \\
\hline $\begin{array}{l}\text { Haematology/ } \\
\text { immunology }\end{array}$ & $\begin{array}{l}\text { Anemia, Neutropenia, } \\
\text { Thrombocytopenia and thrombosis }\end{array}$ & $\begin{array}{l}\text { Complete blood counts, Autoantibody profile: ACL and LA anti } \\
\text {-dsDNA anti -Ro/anti La antibodies, complement C3/C4 levels }\end{array}$ \\
\hline
\end{tabular}

Table 3: Features of pregnancy that can mimic lupus activity.

\begin{tabular}{|lll|}
\hline Features & Pregnancy & SLE \\
\hline Anaemia & $\begin{array}{l}\text { Physiological hydraemia of pregnancy, Iron } \\
\text { deficiency }\end{array}$ & $\begin{array}{l}\text { Anaemia of chronic disease, Haemolytic } \\
\text { anaemia }\end{array}$ \\
\hline Proteinuria & Pre-eclampsia & Nephritis \\
\hline Joint pain and enlargement & Arthralgia/effusion & Inflammatory synovitis \\
\hline Thrombocytopenia & $\begin{array}{l}\text { Gestational hypertension HELLP syndrome, } \\
\text { Pre- Eclampsia, Immune thrombocytopenia }\end{array}$ & Antiphospholipid antibody syndrome \\
\hline Facial rash & Melasmas & Malar rash \\
\hline Seizure & Eclampsia & $\begin{array}{c}\text { Superior saggital sinus thrombosis } \\
\text { Neuropsychiatric lupus }\end{array}$ \\
\hline
\end{tabular}

The contraindication to pregnancy includes:

- $\quad$ Pulmonary artery pressure $>50 \mathrm{~mm} \mathrm{Hg}$ i.e. severe $\mathrm{PH}$

- $\quad$ Advanced renal disease with Serum creatinine $>2.8$ $\mathrm{mg} / \mathrm{dl}$
- $\quad$ Severe restrictive lung disease with Forced vital capacity $<1 \mathrm{~L}$

- Heart failure

- History of severe pre-eclampsia or HELLP syndrome despite therapy

- $\quad$ History of lupus flare within past 6 months 
- $\quad$ Active lupus nephritis

- $\quad$ Stroke within previous 6 months

- Women on drugs like Cyclophosphamide, Mycophenolate Mofetil which are teratogenic.

\section{Antenal period}

The clinician should be aware of the fact that assessment of lupus activity during pregnancy can be difficult as physiological changes of pregnancy are liable to be misinterpreted as flares of the disease.The features of pregnancy mimicking SLE are shown in the Table 3.

The various tests which should be done in the antenatal period include:

- Routine urine analysis

- Haemoglobin, complete blood count total WBC count

- $\quad$ ESR

- Serum creatinine,

- 24 hour urinary total protein

- Anti-dsDNA (raised level indicates active SLE or impending flare)

- Anti-Phospholipid antibodies Anti-Ro(SS-A) and Anti-La (SS-B)

- Serum C3 and C4 level (low C3 indicates active SLE or impending flare)

- Fasting blood glucose

- $\quad$ OGTT 24 to 28 weeks

- Serum lipids (if patient is nephrotic or on steroids)

Out of these tests haemoglobin, blood counts, ESR, routine urine analysis, serum creatinine, anti-ds DNA and C3 levels should be monitored monthly. The antenatal visits for obstetric evaluation should be scheduled at 4 weekly intervals until 20 weeks gestation, 2 weekly intervals until 32 weeks gestation and weekly thereafter. Visits to rheumatologist 4-6 weekly and more frequently if the patient is in active disease or has a disease flare. A primary goal of the antenatal visits after 20 weeks gestation is the detection of hypertension and/ or proteinuria. As there is a risk of utero-placental insufficiency, fetal ultrasonography should be performed every 4 to 6 weeks starting from 18 to 20 weeks of gestation. More frequent ultrasonography and tests for fetal surveillance is indicated in patients with SLE flare, hypertension, proteinuria, clinical evidence of IUGR or antiphospholipid syndrome.

\section{Labor and delivery}

The management of patients with SLE during labour and delivery represents a continuation of her antenatal care. Intravenous glucocorticoid for delivery is recommended in those women who have received maintenance doses or steroid bursts during pregnancy.

\section{Postpartum care}

The postpartum care involves ongoing management and treatment of any associated pregnancy-induced hypertension. They should also be advice regarding contraception and high vigilance should be kept concerning the increased risk of lupus flare in the postpartum period. Maintenance medications should be started immediately after delivery, at similar doses as during pregnancy.

\section{Maternaland fetal complication}

Overall, $20 \%$ of pregnancies to women with SLE will lead to a miscarriage or stillbirth, though the risk of miscarriage is not markedly elevated as compared to the general population however the risk of stillbirth is elevated in several studies. ${ }^{3}$ The predictive factors for foetal loss includes active lupus nephritis, previous history of foetal death and the presence of antiphospholipid antibodies. Foetal loss related to the antiphospholipid syndrome usually occurs in the second and third trimestersThe risk for preterm deliveries is estimated to be $33 \%$ in all lupus pregnancies. ${ }^{3}$ Pregnancy induced hypertension and high steroid doses are responsible for prematurity and IUGR. Lupus patients have an increased risk of pre-eclampsia $5-38 \%$ as compared to women without SLE. ${ }^{4}$

Table 4: Differentiating features between preeclampsia and lupus nephritis.

\begin{tabular}{|lll|}
\hline Lab diagnosis & PIH & Lupus nephritis \\
\hline Hypertension & $\begin{array}{l}\text { After 20 weeks } \\
\text { of gestation }\end{array}$ & $\begin{array}{l}\text { Any time during } \\
\text { pre-pregnancy }\end{array}$ \\
\hline Platelets & Low or normal & Low or normal \\
\hline Complements & Normal or Low & Low \\
\hline Anti dsDNA & Absent & Rising titres \\
\hline Creatinine & $\begin{array}{l}\text { Normal or } \\
\text { raised }\end{array}$ & Normal or raised \\
\hline $\begin{array}{l}\text { Serum Uric } \\
\text { Acid }\end{array}$ & $\begin{array}{l}\text { Elevated greater } \\
\text { than 5.5 mg/dl }\end{array}$ & Normal \\
\hline $\begin{array}{l}\text { 24 hours urine } \\
\text { calcium }\end{array}$ & $\begin{array}{l}\text { Less than 195 } \\
\text { mg/dl }\end{array}$ & $\begin{array}{l}\text { Greater than } \\
195 m g / d l\end{array}$ \\
\hline $\begin{array}{l}\text { Urine } \\
\text { sediments }\end{array}$ & Inactive & Active \\
\hline $\begin{array}{l}\text { Other organs } \\
\text { involved }\end{array}$ & CNS & - \\
\hline $\begin{array}{l}\text { Response to } \\
\text { steroids }\end{array}$ & No & Yes \\
\hline
\end{tabular}

The various risk factors for pre-eclampsia include preexisting hypertension, lupus nephritis and associated antiphospholipid antibodies. The clinical differentiation between pre-eclampsia and renal flare is difficult because both conditions causes hypertension, proteinuria, oedema and deterioration in renal function. The various differentiating features between the two are shown in the Table 4. 


\section{Lupus flare in pregnancy}

Flare may be defined as unpredictable bouts of the disease after a period of remission occurs in 25 to $65 \%$ of patients, develop during the first or second trimester or first few months after delivery. ${ }^{5}$ A number of indices are available for quantifying disease activity or flare of SLE includes "Systemic Lupus Erythematosus Disease Activity Index" and the BILAG "i.e. British Isles Lupus Activity Group". The indicators of flares include exacerbated cutaneous symptoms, new onset or worsening proteinuria, falling serum complement levels, thrombocytopenia leukopenia, raised aminotransferases. The most common organs affected during flare are skin, kidneys, blood and joints and joint flares are less common in pregnancy, hematological and cutaneous manifestations being more common. Around $15-30 \%$ of patients with flare have severe disease manifestations accounting to a maternal mortality of $2-3 \% .^{6}$ Active nephritis at conception increase the risk of disease flare and leads to an adverse pregnancy outcome. The causes of flares include iincreased levels of prolactin (proinflammatory hormone) and increased activity of $\mathrm{T}$ helper cells and cytokines. Most flares are mild and are often treated with small doses of corticosteroids and prophylactic corticosteroids to prevent flare in pregnancy are not recommended.

\section{Drug therapy in SLE in pregnancy}

1) Non Steroidal Anti-inflammatory Drugs (NSAIDs): Non-steroidal anti-inflammatory drugs (NSAIDS) are safe during the first and second trimesters however, moderate associations between use of NSAID in first trimester and specific birth defects are recently reported. ${ }^{7}$ Its use in continuous manner late in the third trimester can increase the risk of premature closure of the ductus arteriosus by almost 15 -fold, and should be avoided. The effect is reversible on discontinuation of medication. They may also cause oligohydramnios due to decreased foetal urine output in late pregnancy.

2) Steroids: Steroid exposure should be limited to a minimum during the pregnancy and higher doses during pregnancy are associated with an increased risk of diabetes, hypertension, pre-eclampsia and premature rupture of membranes. A disease flare requires short courses of high doses and/or intravenous pulse methylprednisolone. Patients on prolong steroid therapy should also receive stress doses at the time of delivery. The use of fluorinated compounds, like dexamethasone and betamethasone should be limited to a single course only for fetal lung maturity, in cases where premature delivery is anticipated. Repeated doses of steroids has been associated with impaired neuro-psychological development of the child in later life, and should be avoided. ${ }^{8}$ Patients with congenital heart block, steroids which cross the placental barrier like betamethasone, dexamethasone should be advised.
Prednisone, prednisolone, methylprednisolone (MPS) have minimal placental transfer and hence are the drugs of choice. In severe disease, pulse therapy of Methyl prednisolone $1000 \mathrm{mg}$ intravenously over 90 minutes for 3 days should be given. Alternatively, $1-2 \mathrm{mg} / \mathrm{kg}$ prednisone can be given orally and after the disease is controlled, the dose is tapered to $10-15 \mathrm{mg}$ OD. There are no major congenital malformations associated with steroids but risk of oral clefts is increased three-fold.

3) Immunosuppressants: Azathioprine is one of the few immunosuppressive agents that is safe during pregnancy and is used in the dose should of $2 \mathrm{mg} / \mathrm{kg} / \mathrm{day}$, to avoid risk of fetal cytopenias and immune suppression. ${ }^{9}$ Other immunosuppressive drugs with no reported increase in fetal risk are the calcineurin inhibitors, tacrolimus and cyclosporine . Other agents, such as cyclophosphamide, methotrexate, and mycophenolate, are contraindicated during pregnancy and should be stopped at least 3 months before conception. ${ }^{9}$ Cyclophosphamide is teratogenic and causes growth restriction, ear and facial abnormalities, absence of digits and hypoplastic limbs and is contraindicated in pregnancy. Severe disease may be treated with cyclophosphamide after 12 weeks of gestation. Mycophenolate mofetil and methotrexate are teratogenic and should be avoided in pregnancy. In some cases, mycophenolate is the only treatment that achieves disease stability and patients should be counselled regarding the foetal risks such as external auditory canal atresia with and without microtia, tracheo-oesophageal atresia, severe hydronephrosis, atrial septal defect, myelomeningocele etc.

4) Hydroxychloroquine: It is an antimalarial drug that has anti-inflammatory properties and helps maintain disease remission. It does not cause congenital malformations and its continuation through pregnancy is recommended.

5) Others: Low-dose aspirin is safe during pregnancy. Heparin does not cross the placenta and is the anticoagulant of choice during pregnancy with SLE in patients having a high risk of thrombosis. Warfarin should be avoided during pregnancy, during the first trimester, due to the risk of warfarin embryopathy syndrome. Calcium supplementation should be given in a routine manner to all pregnant women with SLE to prevent this risk of osteoporosis usually associated with Heparin and steroids.

\section{Lupus nephritis}

About $60 \%$ of patients with SLE develop Lupus nephritis which is associated with inflammation of kidneys characterized by deposition of antigen antibody complexes in renal parenchyma (subendothelium, subepithelium and mesangium). The clinical features includes high blood pressure, foamy, frothy and dark color urine, edema of lower limbs, periorbital edema and 
facial puffiness, weight gain and nocturia. The 6 class of

lupus nephritis are as shown in Table 6.

Table 5: Drugs used in SLE.

\begin{tabular}{|c|c|c|c|c|}
\hline Drugs & FDA & Safe -yes & Unsafe -no & Comments \\
\hline Low dose Aspirin & $\mathrm{C}$ & Yes & & No consensus on when to stop low dose aspirin before delivery \\
\hline NSAIDS & $\mathrm{B}, \mathrm{C}$ & Yes & & Avoid third trimester use \\
\hline Prednisone & B & Yes & & Indicated for Maternal use \\
\hline Dexamethsone & $\mathrm{C}$ & Yes & & Not recommended for routine use \\
\hline Betamethasone & $\mathrm{C}$ & Yes & & Not recommended for routine use \\
\hline Hydroxyquonolines & & Yes & & \\
\hline Methotrexate & $\mathrm{X}$ & & No & \\
\hline Tacrolimus & $\mathrm{C}$ & & Query & May be used at the lowest possible dose \\
\hline Cyclophosphamide & $\mathrm{D}$ & & No & \\
\hline Azathioprine & $\mathrm{D}$ & Yes & & When indicated, azathioprine can be used during pregnancy \\
\hline Cyclosporine A & $\mathrm{C}$ & Yes & & $\begin{array}{l}\text { Can be used for maintenance in pregnancy at the lowest } \\
\text { effective dose }\end{array}$ \\
\hline
\end{tabular}

Table 6: Classes of lupus nephritis.

\begin{tabular}{|ll|}
\hline Class & Histopathology \\
\hline Class I & Minimal Mesangial lupus nephritis \\
\hline Class II & Mesangial Proliferative lupus nephritis \\
\hline Class III & $\begin{array}{l}\text { Focal lupus nephritis (less than 50\% of } \\
\text { glomeruli) }\end{array}$ \\
\hline Class IV & $\begin{array}{l}\text { Diffuse lupus nephritis (greater than 50 } \\
\% \text { of glomeruli) }\end{array}$ \\
\hline Class V & Membranous lupus nephritis \\
\hline Class VI & $\begin{array}{l}\text { Advanced sclerosing lupus nephritis, } \\
90 \% \text { sclerosed }\end{array}$ \\
\hline
\end{tabular}

The Comparative studies on Lupus Nephritis in pregnancy were reviewed and the results are shown in Table 7.

Table 7: Comparative studies of SLE with lupus nephritis in pregnancy with outcome.

\begin{tabular}{|c|c|c|c|}
\hline Studies & $\begin{array}{l}\text { No of } \\
\text { Pregnancies }\end{array}$ & Complications & $\%$ \\
\hline Lockshin $^{10}$ & 125 & $\begin{array}{l}\text { With Nephritis } \\
\text { Without Nephritis }\end{array}$ & $\begin{array}{l}67 \\
14\end{array}$ \\
\hline $\begin{array}{l}\text { Moroni and } \\
\text { Ponticelli }^{11}\end{array}$ & 309 & $\begin{array}{l}\text { Flare of disease } \\
\text { Renal insuffiency } \\
\text { MMR }\end{array}$ & $\begin{array}{l}30 \\
40 \\
13\end{array}$ \\
\hline $\begin{array}{l}\text { Wagner } \\
\text { and Co } \\
\text { worker }^{12}\end{array}$ & & $\begin{array}{l}\text { With active } \\
\text { nephitis without } \\
\text { active nephritis }\end{array}$ & 57 \\
\hline
\end{tabular}

Active lupus nephritis increases the risk of premature birth, foetal death and hypertension. These studies support the current recommendations of avoiding pregnancy unless all manifestations of nephritis are quiescent, thus emphasizing the need for involvement of the Physcian and the rheumatologist in the care of these patients and early recognition of clinical signs of pre- eclampsia. Most recommend continuation of immunosuppressive therapy for nephritis during pregnancy.

\section{Neonatal lupus syndrome}

NLS is a form of passively acquired foetal autoimmunity from maternal antibodies anti-SS-A/Ro or SSB/La ribonucleoproteins which are transmitted in the second trimester. It manifests as cardiac abnormalities, rash, cytopenias and hepatic functional abnormalities. Most manifestations such as rash, cytopenias and hepatic functional abnormalities are transient as the antibodies usually clear over 6-8 months whereas cardiac manifestations of the NLS syndrome are permanent as the maternal antibodies cause permanent damage to the foetal conducting system. The various cardiac manifestations includes conduction defects varying from first degree to complete heart block and cardiomyopathy. ${ }^{13} 2 \%$ of children born to women positive for anti-Ro/anti-La have complete heart block and the risk rises to $16-20 \%$ in the subsequent pregnancies after the birth of an affected child. ${ }^{14-16}$ A fetus with NLE-associated CHB, can present with bradycardia, which may be detected on a routine antenatal assessment or during fetal echocardiography. All women who are positive for anti-SSA/Ro or SSB/La antibodies should be offered screening with fetal echocardiography during 16-24 weeks of gestation. Antenatal treatment includes maternal dexamethasone or betamethasone (which cross the placenta), IVIG and plasmapheresis however conclusive evidence proving their benefit is lacking. Anti-Ro/anti-La anti-bodies should be checked even if patient is asymptomatic and the finding of complete heart block in the infant is diagnosed as seen in one of our case. Cardiac pacing may be required in neonates and children if they are symptomatic, have congestive cardiac failure or in neonates with awake baseline heart rate of less than $55 / \mathrm{min}$. 


\section{Breast feedin in SLE}

Immunosuppressive agents are contraindicated during breast feeding. Short-acting NSAIDs, antimalarials, lowdose prednisolone, warfarin and heparin seem to be safe. Hydroxychloroquine should be used with caution as it may displace bilirubin, causing kernicterus. Because only $5 \%$ of the glucocorticoid dose is secreted in breast milk, prednisone can be used during breastfeeding. If Prednisone is used in higher doses more, than $20 \mathrm{mg}$ once or twice daily then breast milk should be pumped and discarded 4 hours after the last dose to minimize drug exposure to the infant.

\section{Contraception in SLE}

Barrier contraception is the safest contraceptive method in SLE. Progesterone only pills or depot progestogens are safe in lupus. Intra-uterine devices like copper-T which is associated with risk of infection, is best avoided. Permanent sterilization should be advised to patients who have completed their families. The currently available low dose estrogen oral contraceptive pills safe in SLE patients. ${ }^{17}$ OCP are avoided in:

- Antiphospholipid syndrome

- Thromboembolic diseases

- Highly active disease

- Migraine

- Raynaud's phenomenon

\section{CONCLUSION}

Lupus activity is increased in the presence of superabundance of hormones and various physiologic changes of pregnancy which makes distinction between lupus activity and features of normal pregnancy difficult. The increased inflammatory response during a lupus flare can lead to significant maternal and fetal complications. The use of contraception must be emphasized while patients are taking teratogenic medications. Management of SLE in pregnancy requires an orchestrated effort of the patient, obstetrician, rheumatologist, nephrologist and neonatologist.

Funding: No funding sources

Conflict of interest: None declared

Ethical approval: The study was approved by the Institutional Ethics Committee

\section{REFERENCES}

1. Clowse MEB, Jamison MG, Myers E, James AH. National study of medical complications in SLE pregnancies. Arthritis Rheum. 2006;54(9):S263.

2. Clark CA, Spitzer KA, Nadler JN, Laskin CA. Preterm deliveries in women with systemic lupus erythematosus. J Rheumatol. 2003;30(10):2127-32.
3. Cohen-Solal JF, Jeganathan V, Grimaldi CM, Peeva E, Diamond B. Sex hormones and SLE: influencing the fate of autoreactive B cells. Curr Top Microbiol Immunol. 2006;305:67-88.

4. Chakravarty EF, Colon I, Langen ES. Factors that predict prematurity and preeclampsia in pregnancies that are complicated by systemic lupus erythematosus. Am J Obstet Gynecol. 2005;192(6):1897-904.

5. Petri M, Howard D, Repke J. Frequency of lupus flare in pregnancy. The Hopkins Lupus Pregnancy Center experience. Arthritis Rheum. 1991;34(12):1538-45.

6. Ruiz-Irastorza G, Lima F, Alves J, Khamashta MA, Simpson J, Hughes GR, et al. Increased rate of lupus flare during pregnancy and the puerperium: a prospective study of 78 pregnancies. Br J Rheumatol. 1996;35(2):133-8.

7. Hernandez RK, Werler MM, Romitti P, Sun L, Anderka M. Nonsteroidal antiinflammatory drug use among women and the risk of birth defects. Am J Obstet Gynecol. 2012;206(3):228:e221-8.

8. Wapner RJ, Sorokin Y, Mele L, Johnson F, Dudley DJ, Spong CY, et al. Long-term outcomes after repeat doses of antenatal corticosteroids. $\mathrm{N}$ Engl $\mathrm{J}$ Med. 2007;357(12):1190-8.

9. Ostensen M, Lockshin M, Doria A, Valesini G, Meroni $\mathrm{P}$, Gordon $\mathrm{C}$, et al. Update on safety during pregnancy of biological agents and some immunosuppressive antirheumatic drugs. Rheumatology (Oxford) 2008;47(3):28-31.

10. Lockshin MD. Pregnancy does not cause systemic lupus erythematosus to worsen. Arthritis Rheum. 1989;32:665470.

11. Moroni G, Ponticelli C. Pregnancy after lupus nephritis. Lupus. 2005;14(1):89-94.

12. Wagner and coworkers. Maternal and fetal outcomes in pregnant patients with active lupus nephritis. Lupus. 2009 Apr;18(4):342-7.

13. Buyon JP, Clancy RM, Friedman DM. Cardiac manifestations of neonatal lupus erythematosus: guidelines to management, integrating clues from the bench and bedside. Nat Clin Pract Rheumatol. 2009;5(3):139-48.

14. Brucato A, Doria A, Frassi M, Castellino G, Franceschini F, Faden D, et al. Pregnancy outcome in 100 women with autoimmune diseases and anti-Ro/SSA antibodies: a prospective controlled study. Lupus. 2002;11(11):716-21.

15. Izmirly PM, Llanos C, Lee LA, Askanase A, Kim MY, Buyon JP. Cutaneous manifestations of neonatal lupus and risk of subsequent congenital heart block. Arthritis Rheum. 2010;62(4):1153-7.

16. Llanos C, Izmirly PM, Katholi M, Clancy RM, Friedman DM, Kim MY, et al. Recurrence rates of cardiac manifestations associated with neonatal lupus and maternal/fetal risk factors. Arthritis Rheum. 2009;60(10):3091-7.

17. Lateef A, Petri M. Hormone replacement and contraceptive therapy in autoimmune diseases. J Autoimmune. 2012;38(2-3):J170-6.

Cite this article as: Panchbudhe SA, Satia MN, Madhavi J. A series of 6 cases of systemic lupus erythematosus in pregnancy. Int $\mathrm{J}$ Reprod Contracept Obstet Gynecol 2016;5:4342-50. 